\title{
Indigenousasi Sebagai J embatan Pendidikan Karakter dalam PAUD Melalui Learning By Culture
}

\author{
Nelva Rolina \\ nelva_fipuny@yahoo.co.id \\ PGPAUD Universitas Negeri Yogyakarta
}

\begin{abstract}
Abstrak
Bangsa Indonesia sedang mengalami keterpurukan dekade ini, karena minim sekali insan-insan cendikia yang berkarakter. Pendidikan karakter menjadi sangat penting dan menjadi sorotan, sehingga pemerintah mencanangkan pendidikan karakter sebagai simbol dunia pendidikan saat ini. Namun, penanaman karakter yang kuat tidaklah semudah membalik telapak tangan. Seharusnyalah dilakukan sejak usia kanak-kanak. Masa kanak-kanak yang lazim disebut masa keemasan (golden age) sangat rentan terhadap stimulasi, baik itu stimulasi yang benar maupun yang salah. Seperti teori tabularasa, anak dibaratkan kertas putih yang mudah untuk diberi tulisan apapun, atau laksana botol kosong yang bisa diisi air apapun. Hal ini karena dalam otak anak terdapat ribuan neuron yang sedang terkoneksi satu sama lain. Untuk menanamkan karakter sejak masa kanak-kanak, perlu intervensi mendalam pada pendidikan anak usia dini (PAUD) melalui indigenousasi ke-Indonesia-an sebagai jembatannya, yaitu pembelajaran yang kembali pada tradisi dan budaya (learning by culture).
\end{abstract}

Kata kunci: Indigenousasi, Karakter, PAUD

\begin{abstract}
Indonesia is slumped in this era because it has only a few intellectuals who have good character. Character education becomes very important and gets much attention, so the government launched character education as the symbol of education world. However, nurturing strong characters is not as easy as turning one's hand. It ought to be done since the childhood. Child hood time which is commonly named the golden age is the time when children are very susceptible of stimulants, whether it is wrong stimulants, or the right ones. It is similar to the theory of tabula rasa, where children are compared to white paper that is very easy to write on, or as an empty bottle that can be fulfilled with any kinds of water. This is because within a child's brain, there are thousands of neurons which are interconnected. To nurture good character from childhood time, we need thorough interventions in early age education (PAUD) through indegenousation of being Indonesian as the bridge, that is, through learning process that is going back to the tradition and culture (learning by culture).
\end{abstract}

Keywords: indegenousation, character, early age education 


\section{Pendahuluan}

Dekade ini bangsa Indonesia sedang mengalami berbagai krisis, tak terkecuali krisis moral. Pemberitaan tentang dunia kejahatan di televisi, seperti perampokan, pencurian, perkosaan, penipuan dan sebagainya, tentu saja semakin memperlihatkan carut-marutnya bangsa ini. Hal ini terjadi bukan hanya karena sebagian besar masyarakat memiliki karakter yang lemah, tapi juga minimnya pemimpin yang cerdas dan memiliki karakter yang kuat. Padahal, telah melegenda dan ternama bahwa nenek moyang bangsa Indonesia memiliki karakter yang kuat dan mengagumkan. Oleh karena itu, pendidikan karakter menjadi sangat penting dan harus dimulai sejak dini.

Anak belajar dari lingkungan, sehingga lingkungan harus menanamkan karakter pada anak sejak dini dengan sungguh-sungguh. Lingkungan, terutama keluarga, menjadi sumber belajar bagi anak, yaitu sebagai laboratorium bagi pendidikan anak. Kenyataan bahwa jutaan neuron sedang terkoneksi satu sama lain dalam otak anak, menjadikan masa kanakkanak sangat mudah untuk distimulasi, termasuk dalam menanamkan karakter.

Karakter yang ditanamkan pada anak tentu saja karakter yang sesuai dengan falsafah dan budaya bangsa Indonesia. Untuk itu, intervensi yang dilakukan pada PAUD adalah melalui indigenousasi ke-Indonesia-an, yaitu pembelajaran yang kembali pada tradisi dan budaya. Hal tersebut dapat dilakukan dengan learning by culture.

\section{Sekilas Tentang Indigenous}

Slikkerveer dalam Bambang Ismawan (2011) mengatakan bahwa indigenous merupakan pengertian yang mencakup kebiasaan, pengetahuan, persepsi, norma, kebudayaan yang dipatuhi bersama suatu masyarakat (lokal) dan hidup turun- temurun. Kearifan lokal meliputi bidang etika, kesehatan, sosial-kemasyarakatan, kebiasaan bertani, dan menjaga kelestarian lingkungan. Selanjutnya, dalam tim artikata.com lebih memandang indigenous sebagai sebuah kata dan mendefinisikan secara harfiah. Menurut tim artikata.com ini, indigenous termasuk dalam kata sifat (adjective) yang artinya native; produced, growing, or living, naturally in a country or climate; not exotic; not imported. Indigenous ini memiliki sinonim yang bila digambarkan adalah sebagai berikut:

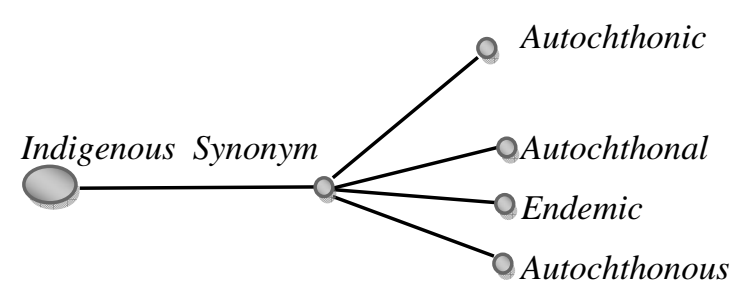

Melihat definisi-definisi di atas, dapat dikatakan bahwa indigenous adalah hal-hal yang bersifat asli dan natural yang mencakup kebiasaan, pengetahuan, persepsi, norma, kebudayaan yang dipatuhi bersama suatu masyarakat (lokal) dan hidup turuntemurun. Indigenousasi dapat dikatakan sebagai pengungkapan kembali keaslian tersebut.

\section{PAUD dan Karakteristiknya}

Usia dini merupakan masa keemasan karena masa ini adalah masa di mana anak sangat potensial untuk distimulasi. NAEYC menyatakan bahwa anak usia dini berkisar antara 0-8 tahun. Namun, menurut Sisdiknas No 20 tahun 2003, anak usia dini meliputi usia 0-6 tahun. Dikatakan sangat potensial diberi stimulasi dikarenakan pada masa ini ribuan neuron terkoneksi satu sama lain. Sesuai prinsip dalam DAP yang menjadi acuan kurikulum PAUD di Indonesia, stimulasi-stimulasi tersebut harus diberikan sesuai tahap perkembangan dan kecerdasan anak, serta dilaksanakan melalui kegiatan bermain. 
Adapun perkembangan anak menurut Permendiknas No 58 Tahun 2009, terbagi menjadi beberapa aspek, yaitu aspek nilai-nilai, moral dan agama, fisik motorik, kognitif, bahasa, dan sosial-emosional.

Senada dengan beberapa aspek tersebut, Gardner (Paul Suparno: 2004) menyatakan bahwa kecerdasan yang dimaksud adalah kecerdasan jamak atau kecerdasan majemuk (multiple intelligences) yang terdiri dari kecerdasan linguistik, kecerdasan matematis-logis, spasial/ruang-visual, kecerdasan jasmani/kinestetik-badani, kecerdasan musikal, interpersonal, kecerdasan intrapersonal, kecerdasan lingkungan (naturalis), dan kecerdasan eksistensial.

a. Perkembangan Fisik Motorik Anak Usia Dini

Perkembangan fisik motorik merupakan dasar bagi perkembangan aspek lainnya. Bila perkembangan fisik motorik terhambat, maka akan mempengaruhi perkembangan aspek selanjutnya. Sebelum membahas tentang perkembangan fisik motorik, akan dibahas terlebih dahulu tentang perkembangan fisik. Menurut Hurlock (2004), perkembangan fisik awal masa kanak-kanak adalah sebagai berikut:

1. pertambahan tinggi badan setiap tahun rata-rata 3 inci;

2. pertambahan berat badan setiap tahun rata-rata 3-5 pon;

3. perbandingan tubuh sangat berubah dan "penampilan bayi" tidak nampak lagi;

4. perbedaan dalam postur tubuh untuk pertama kali tampak jelas dalam awal kanak-kanak;

5. tingkat pengerasan otot bervariasi pada bagian tubuh mengikuti hukum perkembangan arah;

6. anak-anak yang cenderung bertubuh endomorfik (agak gemuk) lebih banyak jaringan lemaknya dari pada jaringan otot; yang cenderung mesomorfik (sedang) mempunyai jaringan otot lebih banyak dari pada jaringan lemak; dan yang cenderung ektomorfik (agak kurus) mempunyai otot-otot yang kecil dan sedikit jaringan lemak;

7. gigi muncul pertama kali di usia 4-6 bulan.

Yulia Ayriza (2005) lebih menyoroti perkembangan fisik anak usia Taman Kanak-kanak/TK (4-6 tahun), meliputi:

1. Anak laki-laki > anak perempuan

2. TB 80-110 cm, BB 10-15 kg

3. Gigi lengkap

4. Otak $75 \%$ ukuran orang dewasa

5. Dasar bagi kemampuan aspek perkembangan yang lain

Selanjutnya adalah pembahasan tentang perkembangan fisik motorik. Secara garis besar, perkembangan fisik motorik terbagi menjadi 2, yaitu perkembangan keterampilam motorik kasar dan perkembangan keterampilan motorik halus. Santrock (2006) mengatakan bahwa keterampilan motorik kasar (gross motor skills) meliputi kegiatan otot-otot besar seperti menggerakkan lengan dan berjalan; dan keterampilan motorik halus (fine motor skills) meliputi gerakan-gerakan menyesuaikan secara lebih halus seperti ketangkasan jari.

Adapun perkembangan keterampilan motorik halus dan kasar pada anak usia pra sekolah (anak usia dini) menurut Yulia Ayriza (2005) dapat dilihat pada tabel 1 berikut ini:

\begin{tabular}{|c|c|}
\hline \multicolumn{2}{|c|}{ Motorik Kasar } \\
\hline Umur 3-4 Tahun & Umur 4-6 Tahun \\
\hline $\begin{array}{l}\text { - Naik turun tangga } \\
\text { - Meloncat } 2 \text { kaki } \\
\text { - Melempar bola }\end{array}$ & $\begin{array}{l}\text { - Meloncat } \\
\text { - Mengendarai } \\
\text { sepeda kecil } \\
\text { - Menangkap bola } \\
\text { - Bermain } \\
\text { olahraga }\end{array}$ \\
\hline \multicolumn{2}{|c|}{ Motorik Halus } \\
\hline Umur 3-4 Tahun & Umur 4-6 Tahun \\
\hline $\begin{array}{l}\text { - Menggunakan } \\
\text { krayon } \\
\text { - Menggunakan } \\
\text { benda/alat }\end{array}$ & $\begin{array}{l}\text { - Menggunakan } \\
\text { pensil } \\
\text { - Menggunakan } \\
\text { gunting }\end{array}$ \\
\hline
\end{tabular}




\begin{tabular}{|l|l|}
\hline - $\begin{array}{l}\text { Meniru } \\
\text { bentuk/gerakan } \\
\text { orang lain }\end{array}$ & \\
\hline
\end{tabular}

Sedangkan perkembangan keterampilan motorik kasar dan motorik halus pada anak usia pra sekolah (anak usia dini) menurut Santrock (2006) adalah sebagai berikut:

\begin{tabular}{|c|c|c|}
\hline \multicolumn{3}{|c|}{ Motorik Kasar } \\
\hline Umur 3 Tahun & $\begin{array}{l}\text { Umur } 4 \\
\text { Tahun }\end{array}$ & $\begin{array}{l}\text { Umur } 5 \\
\text { Tahun }\end{array}$ \\
\hline $\begin{array}{l}\text { - Berjingkrak } \\
\text { - Melompat } \\
\text { - Berlari }\end{array}$ & $\begin{array}{l}\text { - Berjingkra } \\
\text { k } \\
\text { - Melompat } \\
\text { - Berlari } \\
\text { - Memanjat } \\
\text { tangga } \\
\text { dengan } \\
\text { satu kaki }\end{array}$ & $\begin{array}{l}\text { - Memanja } \\
\text { t suatu } \\
\text { obyek } \\
\text { - Berlari } \\
\text { kencang } \\
\text { dan } \\
\text { berlomba } \\
\text { dengan } \\
\text { teman } \\
\text { sebaya }\end{array}$ \\
\hline \multicolumn{3}{|c|}{ Motorik Halus } \\
\hline Umur 3 Tahun & $\begin{array}{l}\text { Umur } 4 \\
\text { Tahun }\end{array}$ & $\begin{array}{l}\text { Umur } 5 \\
\text { Tahun }\end{array}$ \\
\hline $\begin{array}{l}\text { - Menempatk } \\
\text { an dan } \\
\text { memegang } \\
\text { benda } \\
\text { - Memegang } \\
\text { benda kecil } \\
\text { menggunak } \\
\text { an ibu jari } \\
\text { dan telunjuk } \\
\text { - Membangun } \\
\text { menara } \\
\text { tinggi dari } \\
\text { balok } \\
\text { - Menyusun } \\
\text { puzzle } \\
\text { dengan } \\
\text { kasar }\end{array}$ & $\begin{array}{l}\text { - Menyusun } \\
\text { balok } \\
\text { membangu } \\
\text { n menara } \\
\text { dengan } \\
\text { sempurna } \\
\text { - Menyusun } \\
\text { puzzle } \\
\text { lebih halus }\end{array}$ & $\begin{array}{l}\text { - Memban } \\
\text { gun } \\
\text { rumah } \\
\text { atau } \\
\text { gedung } \\
\text { lengkap } \\
\text { dengan } \\
\text { menara } \\
\text { - Lebih } \\
\text { cenderun } \\
\text { g } \\
\text { membuat } \\
\text { sebuah } \\
\text { proyek } \\
\text { dan } \\
\text { mampu } \\
\text { memakn } \\
\text { ainya }\end{array}$ \\
\hline
\end{tabular}

b. Perkembangan Kognitif Anak Usia Dini

Kognitif adalah suatu proses berpikir, yaitu kemampuan individu untuk menghubungkan, menilai dan mempertimbangkan suatu kejadian atau peristiwa (Yuliani Nurani Sujiono, dkk; 2006). Proses kognitif berhubungan dengan tingkat kecerdasan (intelegensi) yang mencirikan seseorang dengan berbagai minat terutama sekali ditujukan kepada ide-ide dan belajar.
Santrock (2006) mengatakan bahwa proses kognitif meliputi perubahan pada pemikiran, inteligensi, dan bahasa individu. Dengan demikian, dapat dikatakan bahwa kognitif merupakan kemampuan individu untuk menghubungkan, menilai dan mempertimbangkan suatu kejadian, serta sangat berhubungan dengan pemikiran, inteligensi, dan bahasa. Kemampuan individu tersebut (tidak hanya kognitif, namun aspek lainnya) berkembang sejak lahir sampai akhir hayat yang dikenal sebagai life span development. Bahasan kali ini tentu saja fokus kepada perkembangan kognitif anak usia dini.

Yulia Ayriza (2005) berpendapat bahwa ada kaitan antara perkembangan kognitif dengan perkembangan fisik motorik pada anak usia dini, khususnya anak usia TK. Kaitan antara keduanya meliputi:

1. Mengenal dan mampu mengidentifikasi bagian-bagian tubuh

2. Memahami perbedaan fisik individu

3. Menerima keterbatasan kemampuan fisik (bisa lari tapi tidak bisa terbang)

4. Memahami kebutuhan tubuh: makan, minum, istirahat, dsb

5. Kesadaran sensori: mata, telinga, kulit, hidung, pencecap

6. Memahami keterbatasan fisik: sakit, lelah, dll

Pendapat senada diungkapkan Hurlock (2004), bahwa bertambah besarnya koordinasi dan pengendalian motorik, serta meningkatnya kemampuan bicara untuk bertanya, maka pengertian anak tentang lingkungan sekitar meningkat pesat. Pengertian tersebut tentu saja diperoleh dari kemampuan intelektual (kognitif), terutama kemampuan berpikir dan melihat hubungan-hubungan.

Karakter anak usia dini memang unik, tak terkecuali perkembangan kognitifnya. Dunia kognitif anak-anak prasekolah (anak usia dini) ialah 
kreatif, bebas, dan penuh imajinasi (Santrock, 2006). Dalam aplikasi seni misalnya, bagi mereka matahari kadang-kadang berwarna hijau, dan langit berwarna kuning. Atau, mobil mengambang di awan, burung pelican mencium anjing laut, dan manusia seperti kecebong.

Perkembangan kognitif anak usia dini meliputi (Yulia Ayriza, 2005):

1. Berpikir konvergen (memusat) menuju ke suatu jawaban yang paling mungkin dan paling benar terhadap suatu persoalan.

2. Tahap praoperasional (Piaget), yaitu:

a. Anak belum mampu menguasai operasi mental secara logis,

b. Fungsi simbolis $\rightarrow$ penguasaan bahasa semakin sistematis,

c. Egosentris $\rightarrow$ tidak mampu melihat dari perspektif orang lain,

d. Imitasi $\rightarrow$ peniruan besarbesaran,

e. Centralized $\rightarrow$ berpikir terpusat pada satu dimensi,

f. Berpikir tidak dapat dibalik, dan

g. Berpikir terarah statis.

3. Vygotsky: stimulasi kognitif di ZPD (Zone of Proximal Development) $\rightarrow$ wilayah dekat kematangan (potensial dan sensitif untuk distimulasi).

Selanjutnya, Yulia Ayriza (2005)

juga mengungkapkan bahwa proses pengembangan kemampuan dasar daya pikir (kognitif) meliputi:

1. Identifikasi: mengenal nama, benda, bilangan, dll.

2. Diferensiasi: membedakan.

3. Klasifikasi: mengelompokkan.

4. Eksperimen: triall and error.

5. Menarik kesimpulan.

6. Generalisasi untuk penguasaan konsep-konsep.

7. Deskripsi: menceritakan, menggambarkan, mengekspresikan.

8. Kolaborasi dengan orang dewasa atau anak yang lebih tua usianya. c. Perkembangan Bahasa Anak Usia Dini

Aspek pengembangan

berbahasa perlu diperhatikan karena bahasa merupakan sarana komunikasi yang efektif. Di dunia, telah banyak yang mempelajari tentang pengembangan aspek berbahasa. Bahkan telah dilakukan beberapa penelitian untuk mengetahui misteri pengembangan aspek berbahasa. Seperti dikutip oleh Smart dan Smart, K. Lovell dari University of Leed, England mengatakan bahwa "Five issues were studied about school-age children: language, personality, mathematical attainment, logical thought, and relationship between scores obtained on so called creativity test and those obtained on test of logical thinking" (1973). Pernyataan tersebut kurang lebih menyatakan bahwa ada lima persoalan yang dipelajari tentang anak usia sekolah, yaitu bahasa, kepribadian, penguasaan matematika, gagasan yang logis, dan hubungan antara perolehan skor pada test kreativitas dengan perolehan skor pada test berpikir logis. J elas sekali bahwa pengembangan aspek bahasa dianggap penting dalam perkembangan seorang anak.

Adapun perkembangan bahasa anak usia dini menurut Lewin dkk (2005) adalah sebagai berikut:

1. Anak yang masih kecil

Keterampilan verbal

- Mengucapkan kata-kata sederhana, bisanya kata-kata dengan satu atau dua suku kata

- Menyuarakan berbagai bunyi (bahkan seandainya bunyi itu tidak dapat dimengerti oleh orang dewasa)

Keterampilan membaca

- Mengenali (tidak harus membaca) abjad dan kata, seperti tanda McDonald

- Menikmati mengamati buku, membalik-balik halaman dan ingin tahu akan isinya 
2. Anak yang lebih besar

Keterampilan verbal

- Berbicara dalam kalimat

- Memahami dan mengikuti perintah

- Menirukan dan memainkan peran

- Merangkai kata-kata untuk berkomunikasi

Keterampilan membaca/menulis

- Berusaha untuk menulis abjad dasar

- Mulai membaca kata-kata sederhana

- Mengenal abjad dengan baik

- Memperlihatkan minat terhadap buku-buku

Hurlock (2004) lebih menyoroti

pada kemampuan bicara. Menurutnya, tugas dalam belajar bicara pada masa kanak-kanak meliputi:

1. Pengucapan kata-kata

Anak-anak sulit belajar mengucapkan bunyi tertentu dan kombinasi bunyi, seperti huruf mati z, w, d, s, dan g, dan kombinasi huruf mati st, str, dr, dan fl. Mendengarkan radio dan televisi dapat membantu belajar mengucapkan kata-kata secara benar.

2. Menambah kosakata

Kosakata anak-anak meningkat pesat ketika ia belajar kata-kata baru dan arti-arti baru untuk kata-kata lama. Dalam menambah kosakata anak-anak muda belajar kata-kata yang umum seperti "baik" dan "buruk", "memberi" dan "menerima", serta banyak kata-kata dengan penggunaan khusus seperti bilangan dan namanama warna.

3. Membentuk kalimat

Kalimat biasanya terdiri dari tiga atau empat kata sudah mulai disusun oleh anak usia dua tahun dan biasanya oleh anak usia tiga tahun. Kalimat ini banyak yang tidak lengkap, terutama terdiri dari kata benda dan kurang kata kerja, kata depan dan kata penghubung. Sesudah usia tiga tahun, anak membentuk kalimat yang terdiri dari enam sampai delapan kata.
Anggani Sudono (2000) mengutip Lerner (1982) menyatakan bahwa dasar utama perkembangan bahasa adalah melalui pengalaman-pengalaman berkomunikasi yang menunjang faktor-faktor bahasa yang lain, diantaranya mendengarkan, berbicara, membaca dan menulis. Mendengarkan dan membaca termasuk keterampilan berbahasa yang menerima atau reseptif. Sedangkan berbicara dan menulis merupakan keterampilan yang ekspresif. Hal tersebut senada dengan pendapat Soemiarti Patmonodewo (2000) yang menyatakan bahwa terdapat dua pertumbuhan bahasa yaitu bahasa yang bersifat reseptif dan bahasa yang bersifat ekspresif. Bahasa reseptif menunjukkan kemampuan anak untuk memahami dan berlaku terhadap komunikasi yang ditujukan kepadanya. Sedangkan bahasa ekspresif menunjukkan ciptaan bahasa yang dikomunikasikan kepada orang lain. Kedua pertumbuhan bahasa tersebut merupakan kriteria dalam mengetahui perkembangan bahasa anak.

d. Perkembangan Seni Anak Usia Dini

Untuk menjadikan anak cerdas, kreatif, dan berkarakter, memang harus distimulasi sejak dini. Salah satu upaya untuk itu adalah memberikan aktivitas seni dalam kegiatan bermainnya. Diketahui, usia dini merupakan periode emas untuk melakukan proses stimulasi aktif sebagai bekal perkembangan serta pertumbuhan kelak saat dewasa. Pada usia dini, anak sudah mampu menerima keterampilan dan pengajaran sebagai dasar pengetahuan dan proses berpikir melalui otak.

Pada dasarnya, otak manusia dibagi menjadi dua bagian, yaitu otak kiri dan otak kanan dengan fungsi yang berbeda. Otak kiri biasa diidentikkan dengan rapi, perbedaan, angka, urutan, tulisan, bahasa, hitungan, logika, terstruktur, analitis, matematis, sistematis, linear dan tahap demi tahap; sedangkan otak kanan diidentikkan 
dengan kreativitas, persamaan, khayalan, kreativitas, bentuk atau ruang, emosi, musik dan warna, berpikir lateral, tidak terstruktur, dan cenderung tidak memikirkan hal-hal yang terlalu mendetail (Nelva Rolina, 2010). Untuk mencapai anak yang cerdas, kedua belah otak ini harus distimulasi secara bersamaan (termasuk yang mengembangkan aspek seni).

Fabiola Priscilla Setiawan (2010) menyatakan bahwa pendidikan seni berperan penting untuk merangsang perkembangan belahan otak bagian kanan anak. Pelajaran seni terbukti dapat meningkatkan kepandaian berekspresi anak, pemahaman sisi-sisi kemanusiaan, kepekaan dan konsentrasi yang tinggi, serta kreativitas yang gemilang. Dengan begitu, diharapkan anak yang diberikan kebebasan untuk me-ngembangkan bakat seninya seperti melukis, menulis puisi, bernyanyi atau bermain alat musik, akan mudah menapaki tangga menuju puncak prestasi.

Orang tua tentu bangga dengan pencapaian buah hatinya tersebut. Contohnya adalah pada saat anak melukis, biasanya pikirannya akan mengingat benda atau seseorang yang pernah dilihatnya. Dengan begitu, daya ingatnya akan terus terasah. Melukis juga mengembangkan kreativitas anak karena membuat sesuatu dari tidak ada menjadi ada. Banyak gagasan lama menjadi baru saat anak menggambar. Misalnya saat melukis gunung, dia akan menambah gambar burung atau sawah. Padahal, dari pemandangan gunung yang dia lihat sendiri tidak ada burung. Ini menunjukkan tingkat kreativitas anak mulai tumbuh. Melukis juga dapat menambah perbendaharaan bahasa dan kosakata anak. Caranya, biarkan dia menceritakan gambar apa saja yang baru dia buat. Tidak hanya menjelaskan gambar, minta dia membuat kisah dibaliknya. Daya khayal dan imajinasi anak juga mulai dikembangkan pada saat itu.
Sementara dari sisi emosi, pendidikan seni dapat berfungsi sebagai alat untuk mengasah kepekaan dan rasa kepedulian sosial anak. Dengan membuat puisi misalnya, anak akan berusaha mengeluarkan pendapat dan perasaan yang terpendam di lubuk hatinya ketika melihat kondisi lingkungan terdekatnya. Anak akan lebih peka dan perhatian dengan apa-apa saja kejadian yang terjadi pada dirinya dan sekelilingnya. Rasa empati terhadap penderitaan dan kesusahan orang lain juga ikut terlatih.

Pengembangan seni pada anak juga dapat dijadikan sarana mengeluarkan emosi secara sehat tanpa menyakiti atau mengganggu orang lain. Dia bisa nyanyi dengan teriak-teriak, mencoret-coret buku gambar, atau menari sesuka hati saat marah. Emosinya jadi diluapkan dengan berkesenian. Fungsi seni juga dapat meningkatkan kepercayaan diri. Saat anak tampil di atas panggung atau di depan temantemannya untuk mempertunjukkan bakatnya, dia merasa kelebihannya itu bisa membuat dirinya bangga. Menari dan musik juga dapat mengasah gerakan motorik kasarnya karena selalu bergerak.

e. Perkembangan Sosial Emosional Anak Usia Dini

Santrock (2006) menyatakan bahwa perkembangan sosial emosional anak tergantung pada gaya pengasuhan dalam keluarga. Gaya pengasuhan tersebut terbagi menjadi empat kategori utama, yaitu otoriter, otoritatif, permissive-indifferent, dan permissive-indulgent. Pengasuhan otoritatif diasosiasikan dengan kompetensi sosial anak lebih daripada gaya-gaya pengasuhan yang lain. Pengasuhan otoritatif merupakan pola pengasuhan anak yang paling umum di seluruh dunia. Keluarga kelas pekerja dan berpenghasilan rendah menaruh nilai yang lebih tinggi pada karakteristik eksternal, sedangkan orang tua kelas menengah menaruh nilai yang 
lebih tinggi pada karakteristik internal, dan kelas-kelas social ini bervariasi dalam hal pola-pola pengasuhan anak.

Erik $\mathrm{H}$ Erickson dalam Ns. Anisah Ardiana (2007) mengungkapkan teori psikososial dengan tahapan berikut:

1. trust vs mistrust -- bayi (lahir - 12 bulan)

2. otonomi vs ragu-ragu dan malu (autonomy vs shame \& doubt) -toddler (1-3 tahun)

3. inisiatif vs merasa bersalah (initiative vs guilt) -- pra sekolah ( 3-6 tahun)

4. industri vs inferior (industry vs inferiority) -- usia sekolah (6-12 tahun)

5. identitas vs bingung peran (identity vs role confusion) -- remaja (12 - 18 tahun)

6. intimasi vs isolasi (intimacy vs isolation) - dewasa muda (18-25 sampai 45 tahun)

7. generativitas vs stagnasi atau absobsi diri - dewasa tengah (45 65 tahun)

8. integritas ego vs putus asa -- dewasa akhir (65 tahun keatas)

Tahapan yang sesuai dengan bahasan ini adalah tahapan kedua dan ketiga. Hal tersebut dapat terlihat pada tabel 2 berikut ini:

\begin{tabular}{|c|c|}
\hline $\begin{array}{l}\text { Otonomi vs } \\
\text { ragu-ragu dan } \\
\text { malu (autonomy } \\
\text { vs shame \& } \\
\text { doubt) } \\
1-3 \text { tahun }\end{array}$ & $\begin{array}{c}\text { Inisiatif vs merasa } \\
\text { bersalah } \\
\text { (initiative vs } \\
\text { guilt) } \\
\text { 3-6 tahun }\end{array}$ \\
\hline $\begin{array}{l}\text { 1. Indikator } \\
\text { positif: kontrol } \\
\text { diri tanpa } \\
\text { kehilangan } \\
\text { harga diri } \\
\text { 2. Indikator } \\
\text { negatif: } \\
\text { terpaksa } \\
\text { membatasi diri } \\
\text { atau terpaksa }\end{array}$ & $\begin{array}{l}\text { 1. Indikator } \\
\text { positif: } \\
\text { mempelajari } \\
\text { tingkat } \\
\text { ketegasan dan } \\
\text { tujuan } \\
\text { mempengaruhi } \\
\text { lingkungan. } \\
\text { Mulai } \\
\text { mengevaluasi }\end{array}$ \\
\hline
\end{tabular}

\begin{tabular}{|c|c|}
\hline $\begin{array}{l}\text { mengalah } \\
\text { 3. Anak mulai } \\
\text { mengembangk } \\
\text { an kemandirian } \\
\text { membuka dan } \\
\text { memakai baju, } \\
\text { berjalan, } \\
\text { mengambil, } \\
\text { makan sendiri, } \\
\text { dan ke toilet. } \\
\text { Mulai } \\
\text { terbentuk } \\
\text { kontrol diri. } \\
\text { 4. Jika } \\
\text { kemandirian } \\
\text { todler tidak } \\
\text { didukung oleh } \\
\text { orang tua, } \\
\text { mungkin anak } \\
\text { memiliki } \\
\text { kepribadian } \\
\text { yang ragu-ragu } \\
\text { 5. jika anak } \\
\text { dibuat merasa } \\
\text { buruk pada } \\
\text { saat melakukan } \\
\text { kegagalan, } \\
\text { anak akan } \\
\text { menjadi } \\
\text { pemalu. }\end{array}$ & $\begin{array}{l}\text { kebiasaan } \\
\text { (perilaku) diri } \\
\text { sendiri. } \\
\text { 2. Indikator } \\
\text { negatif: kurang } \\
\text { percaya diri, } \\
\text { pesimis, takut } \\
\text { salah. } \\
\text { Pembatasan dan } \\
\text { kontrol yang } \\
\text { berlebihan } \\
\text { terhadap } \\
\text { aktivitas pribadi } \\
\text { 3. Inisiatif, } \\
\text { mencoba hal-hal } \\
\text { baru, perilaku } \\
\text { kuat, imajinatif } \\
\text { dan intrusif, } \\
\text { perkembangan } \\
\text { perasaan } \\
\text { bersalah dan } \\
\text { identifikasi } \\
\text { dengan orang } \\
\text { tua yang } \\
\text { berjenis kelamin } \\
\text { sama. } \\
\text { 4. Pembatasan --- } \\
\text { mencegah anak } \\
\text { dari } \\
\text { perkembangan } \\
\text { inisiatif. } \\
\text { 5. Rasa bersalah } \\
\text { mungkin } \\
\text { muncul pada } \\
\text { saat melakukan } \\
\text { aktivitas yang } \\
\text { berlawanan } \\
\text { dengan orang } \\
\text { tua. } \\
\text { 6. Anak perlu } \\
\text { belajar untuk } \\
\text { memulai } \\
\text { aktivitas tanpa } \\
\text { merusak hak- } \\
\text { hak oranglain. } \\
\text { para }\end{array}$ \\
\hline
\end{tabular}

Pendapat yang berbeda dan lebih kompleks adalah pendapat dari Hurlock (2004). Hurlock memilah perkembangan sosial emosial secara terpisah, yaitu perkembangan sosial dan 
perkembangan emosi. Perkembangan sosial anak dapat dilihat dari pola perilaku sosial dan tidak sosial pada anak. Pola-pola perilaku sosial dan tidak sosial tersebut dapat dilihat dalam tabel berikut:

\begin{tabular}{|l|l|}
\hline \multicolumn{1}{|c|}{$\begin{array}{c}\text { Pola Perilaku } \\
\text { Sosial }\end{array}$} & \multicolumn{1}{|c|}{$\begin{array}{c}\text { Pola Perilaku } \\
\text { Tidak Sosial }\end{array}$} \\
\hline 1. Meniru & 1. Negativisme \\
2. Persaingan & 2. Agresif \\
3. Kerja sama & 3. Perilaku \\
4. Simpati & berkuasa \\
$\begin{array}{l}\text { 5. Empati } \\
\text { 6. Dukungan }\end{array}$ & 4. Memikirkan \\
sosial & diri sendiri \\
7. Membagi & 5ementingka \\
$\begin{array}{l}\text { 8. Perilaku } \\
\text { akrab }\end{array}$ & 6. Merusak \\
& 7. Pertentangan \\
& 8eks \\
\hline
\end{tabular}

Perkembangan emosi anak pun dapat dilihat dari pola emosinya. Selanjutnya, Hurlock mengungkapkan emosi-emosi yang umum pada awal masa kanak-kanak, yaitu: amarah, takut, cemburu, ingin tahu, iri hati, gembira, sedih, dan kasih sayang.

f. Perkembangan Moral dan Nilai-nilai Agama Anak Usia Dini

Aspek moral dan nilai-nilai agama merupakan salah satu kemampuan bidang pembiasaan yang harus dikembangkan pada diri anak. Pada masa ini (kanak-kanak awal), perkembangan moral anak masih dalam tingkat rendah (Hurlock, 2004). Hal tersebut disebabkan karena perkembangan intelektual anak-anak belum mencapai titik di mana ia dapat mempelajari atau menerapkan prinsipprinsip abstrak tentang benar dan salah. Selain itu, ia juga tidak mempunyai dorongan untuk mengikuti peraturan-peraturan karena tidak mengerti manfaatnya sebagai anggota kelompok sosial. Maka dari itu, karena anak tidak mampu mengerti masalah standar moral, ia harus belajar berperilaku moral dalam pelbagai situasi yang khusus.
Ahli yang menyoroti tentang perkembangan moral adalah Kohlberg (1968). Kohlberg dalam Ns. Anisah Ardiana (2007) membagi perkembangan moral manusia menjadi 3 tahapan, yaitu:

1. Tingkat premoral

(prekonvensional): lahir sampai 9 tahun

2. Tingkat moralitas konvensional: 913 tahun

3. Tingkat moralitas pasca konvensional: 13 tahun sampai meninggal

Anak usia dini termasuk dalam tingkat premoral (prekonvensional) yaitu sejak lahir sampai usia 9 tahun. Adapun ciri-ciri dari tingkat premoral menurut Kohlberg (Ns. Anisah Ardiana, 2007) adalah sebagai berikut:

1. Kewaspadaan terhadap moral yang bisa diterima secara sosial

2. Kontrol didapatkan dari luar.

3. Anak menggabungkan label baik dan buruk, benar dan salah dalam perilaku

4. Tawar menawar, pembagian yang seimbang dan kejujuran menjadi muncul

5. Hidup dinilai dengan bagaimana anak dapat memuaskan kebutuhan dari orang lain.

Selanjutnya, tingkat premoral ini terbagi menjadi 2 tahap, yaitu:

1. Tahap orientasi hukuman dan kepatuhan (lahir - 6 tahun):

Peraturan diikuti untuk menghindari hukuman

2. Tahap orientasi egoistik secara sederhana (6-9 tahun):

Anak menyesuaikan minat diri sendiri dengan aturan, berasumsi bahwa penghargaan atau bantuan akan diterima.

Menurut Santrock (2006), studi tentang perilaku moral telah dipengaruhi oleh teori belajar sosial. Proses-proses penguatan, Penghu-kuman, dan peniruan digunakan untuk menjelaskan perilaku moral anakanak. Perkembangan moral berkaitan 
dengan aturan-aturan dan ketentuanketentuan tentang apa yang seharusnya dilakukan oleh orang-orang dalam interaksi mereka dengan orang lain. Para pakar perkembangan anak mempelajari bagaimana anak-anak berpikir, berperilaku, dan merasa tentang aturan-aturan dan ketentuanketentuan tersebut. Melalui identifikasi, anak-anak menginternalisasikan standard perilaku benar atau salah orang tua. Anak-anak menaati standard masyarakat untuk menghindari rasa bersalah.

Untuk perkembangan nilai-nilai agama, Gardner dalam Paul Suparno (2004) membahasakan dengan kecerdasan eksistensial/spiritual, yaitu bagaimana seseorang memahami eksistensi dirinya serta hubungannya dengan sang pencipta. Pada anak-anak, memahami hal yang berhubungan dengan ketuhanan masih dalam taraf yang sederhana, yaitu batas pengenalan dan penerapan dalam kehidupan sehari-hari melalui pembiasaan di rumah maupun di sekolah. Kegiatan pembelajaran dalam PAUD merupakan kegiatan pembelajaran yang terpadu berupa kegiatan bermain serta dinaungi sebuah tema (tematik). Dengan demikian, semua aspek di atas mempunyai keterkaitan satu sama lain dalam pen-stimulasi-annya. Yang paling erat hubungannya dengan pembentukan karakter anak usia dini adalah aspek perkembangan sosial emosional serta aspek moral dan nilainilai agama.

\section{Pendidikan Karakter}

Karakter adalah kualitas atau kekuatan mental atau moral, akhlak atau budi pekerti individu yang merupakan kepribadian khusus yang menjadi pendorong dan penggerak, serta yang membedakan dengan individu lain (Furqon Hidayatullah, 2010). Hampir senada dengan pendapat tersebut, Agbenyega (2011) menyatakan bahwa karakter adalah jalan hidup yang berkembang melalui nilai dan keyakinan serta tidak bersifat universal. Nilai tersebut dikembangkan melalui sejarah. Kamus Besar Bahasa Indonesia karangan W.J.S. Poerwadarminta (2007) dinyatakan bahwa nilai adalah harga, hal-hal yang penting atau berguna bagi kemanusiaan. Oleh karena itu, karakter terbentuk berdasarkan kontaminasi lingkungan sekitar dan beririsan dengan budaya. Misalnya, karakter bangsa Indonesia yang berbudi luhur, cerdas, dan beragama diwariskan turun temurun sejak jaman nenek moyang sesuai budaya bangsa Indonesia yang beraneka ragam.

Pendidikan karakter dilakukan dengan menanamkan karakter tersebut pada peserta didik. Tujuan dari pendidikan karakter ini, tentu saja untuk membangun peradaban bangsa. Untuk mewujudkan tujuan tersebut, tentu harus lebih memahami apa dan bagaimana pendidikan karakter tersebut. Berdasarkan hadits yang dirangkum dan dianalisis, Furqon Hidayatullah (2010) mengatakan bahwa pendidikan karakter dapat diklasifikasikan dalam tahap-tahap sebagai berikut:

1. Adab (5-6 tahun)

Pada fase ini, anak didik budi pekerti, terutama yang berkaitan dengan nilai-nilai karakter: jujur (tidak berbohong), mengenal mana yang benar dan mana yang salah, mengenal mana yang baik dan mana yang buruk, serta mengenal mana yang diperintah (yang dibolehkan) dan mana yang dilarang (yang tidak boleh dilakukan).

2. Tanggungjawab diri (7-8 tahun)

Perintah agar anak usia 7 tahun mulai menjalankan sholat menunjukkan bahwa anak mulai dididik untuk bertanggung jawab, terutama dididik bertanggung jawab pada diri sendiri. Anak mulai diminta untuk membina dirinya sendiri, anak mulai dididik untuk memenuhi kebutuhan dan kewajiban dirinya sendiri. 


\section{Caring-peduli (9-10 tahun)}

Setelah anak dididik tentang tanggung jawab diri, maka selanjutnya anak dididik untuk mulai peduli pada orang lain, terutama teman-teman sebaya yang setiap hari ia bergaul. Menghargai orang lain (hormat kepada yang lebih tua dan menyayangi kepada yang lebih muda), menghormati hak-hak orang lain, bekerja sama di antara teman-temannya, serta membantu dan menolong orang lain, merupakan aktivitas yang sangat penting pada masa ini.

\section{Kemandirian (11-12 tahun)}

Berbagai pengalaman yang telah dilalui pada usia-usia sebelumnya makin mematangkan karakter anak sehingga akan membawa anak kepada kemandirian. Pada masa ini, anak sudah mulai dilatih untuk berpisah tempat tidur dengan orang tuanya. Pada fase kemandirian ini berarti anak telah mampu menerapkan terhadap hal-hal yang menjadi perintah dan yang menjadi larangan, serta sekaligus memahami konsekuensi resiko jika melanggar aturan.

5. Bermasyarakat (13 tahun ke atas)

Tahap ini merupakan tahap di mana anak dipandang telah siap memasuki kondisi kehidupan di masyarakat. Anak diharapkan telah siap bergaul di masyarakat dengan berbekal pengalaman-pengalaman yang dilalui sebelumnya. Setidak-tidaknya ada dua nilai penting yang harus dimiliki anak walaupun masih bersifat awal atau belum sempurna, yaitu integritas dan kemampuan beradaptasi

Melihat kelima tahapan tersebut, anak usia dini masuk pada tahapan pertama dan kedua karena yang termasuk anak usia dini adalah anak yang berusia 0-6 tahun (Sisdiknas No 20 Tahun 2003). Namun, karakter tetap dapat ditanamkan sebelum usia 5 tahun dengan strategi dan cara yang tepat. Ada strategi dan cara yang tepat dalam mengaplikasikan pendidikan karakter, terutama pada anak usia dini.
Selanjutnya akan dibahas tentang strategi dan cara tersebut dalam subjudul indigenousasi sebagai pendidikan karakter AUD dengan learning by culture.

\section{Indigeounisasi Sebagai J embatan Pendidikan Karakter Pada PAUD Melalui Learning By Culture}

Melihat karakteristik AUD di atas, jelas sekali bahwa masa kanakkanak atau biasa disebut sebagai golden age merupakan masa yang sangat potensial untuk distimulasi. Seperti teori tabularasa dari John Locke yang menyatakan bahwa anak diibaratkan kertas putih kosong yang bebas ingin ditulis dengan tulisan apa, dan laksana botol kosong yang bebas diisi air apa saja. Dalam membentuk karakter pun demikian. Anak sangat potensial untuk distimulasi dalam pembentukan karakter. Tentu karakter yang sesuai dengan budaya bangsa Indonesia tentunya.

Secara umum, ada strategi pembentukan karakter yang dapat dilakukan pada PAUD menurut Furqon Hidayatullah (2010), yaitu: keteladanan, penanaman/ penegakan kedisiplinan, pembiasaan, menciptakan suasana yang kondusif, serta integrasi dan internalisasi. Hasil akhir dari strategi ini tentu saja tidak terlepas dari peran serta guru dan orang tua. Untuk itu, guru dan orang tua harus pula memahami bagaimana cara pembentukan karakter pada AUD ini. Kelima strategi tersebut dapat dirangkum menjadi satu kesatuan utuh melalui indigenousasi.

Indigenousasi merupakan jembatan dalam PAUD untuk memb-entuk karakter anak. Indigenousasi yang dimaksud adalah melalui learning by culture. Membangkitkan kembali atau memunculkan kembali nilai-nilai budaya yang hampir punah. Anak diharapkan belajar melalui budaya, dengan budaya, dan dalam budaya. Budaya itu sendiri dapat dimunculkan melalui media-media pembelajaran 
dan sumber belajar (baik by design, maupun by utilization). Lingkungan yang berbudaya asli Indonesia dapat dijadikan sumber belajar bagi anak. Selain itu, tata cara atau adat istiadat yang biasa di lakukan di masyarakat dapat dijadikan sumber belajar dalam pembentukan karakter anak. Pemunculan dongeng-dongeng klasik asli Indonesia pun dapat dijadikan jembatan sebagai pembentukan karakter anak (misal: Si Malin Kundang, Roro J ongg-Rang, Bawang Putih dan Bawang Merah, Kleting Kuning, J aka Tarub, dan lain-lain). Melalui dongeng-dongeng klasik tersebut, anak dapat melihat karakter-karakter tokohtokoh yang ada dalam dongeng tersebut.

Indigenousasi ini dapat pula dilakukan dengan memunculkan nilainilai karakter dalam sebuah keutuhan menyangkut budaya Indonesia. Misalnya adalah karakter kepemimpinan Asthabrata, karakter kepemimpinan dalam serat Wulang Reh, karakter kepemimpinan dalam Dasa Dharma Raja, dan karakter kepemimpinan Astha Dasa Kotamaning Prabu. Karakter-karakter tersebut dapat disampaikan pada anak sehingga terbentuk karakter yang sesuai dengan budaya bangsa Indonesia.

\section{Penutup}

Indigenousasi dapat dijadikan jembatan pendidikan karakter dalam PAUD melalui learning by culture. Dengan memunculkan kembali hal-hal yang hampir punah mengenai budaya bangsa Indonesia, dapat membentuk karakter AUD sesuai dengan budaya bangsa Indonesia. Intervensi ini dilakukan pada PAUD dengan tidak terlepas dari peran orang tua dan guru yang juga member teladan bagi anak. Selain pembentukan karakter lebih optimal, sejak dini anak akan lebih mengenal budaya bangsanya yang membanggakan.

\section{Daftar Pustaka}

Agbenyega, J S. 2011. Developing Future Leaders in Early Childhood Education. Hand book of International Workshop. J akarta, Indonesia.

Ardiana, Ns. Anisah. 2007. Konsep Pertumbuhan dan Perkembangan Manusia (Diktat, tidak dipublikasikan). J ember: Prodi Ilmu Keperawatan Universitas J ember.

Ayriza, Yulia. 2005. Perkembangan Anak Usia SD dan TK (Makalah yang disampaikan dalam Srawung Akademik Dosen Baru FIP UNY, tidak dipublikasikan). Yogyakarta: FIP UNY.

Hidayatullah, Furqon. 2010. Pendidikan Karakter: Membangun Peradaban Bangsa. Surakarta: Yuma Pustaka.

Hurlock, EB. 2004. Psikologi Perkembangan. J akarta: Penerbit Erlangga.

Ismawan, Bambang. 2011. Indigenous Knowledge.forsino.wordpress.co $\mathrm{m}$.

Kurikulum TK. 2004. Kurikulum Berbasis Kompetensi Taman Kanak-kanak 2004. Jakarta: DEPDIKNAS.

Lwin, May dkk. 2005. How to Multiply Your Child's Intelligence (Cara Mengembangkan Berbagai Komponen Kecerdasan). J akarta: PT. Indeks.

Padmonodewo, Soemiarti. 2000. Pendidikan Anak Prasekolah. Jakarta: Depdikbud dan Rineka Cipta. 
Poerwadarminta, W.J.S.. 2007. Kamus Besar Bahasa Indonesia. Indonesia.

Rolina, Nelva. 2010. Memahami Psikologi Perkembangan Anak Bagi Pengembangan Aspek Seni Anak Usia Dini. Artikel yang disampaikan pada TOT P4TK-SB, Tidak Diterbitkan.

Santrock, JW. 2006. Life Span Development (Edisi Kelima). J akarta: Penerbit Erlangga.

Setiawan, Fabiola Priscilla. 2010. Anak Cerdas dan Berkarakter Berkat Seni. lifestyle.okezone.com.

Smart, MS and Smart, RC. 1973. School-Age Children (Development and Relationships). New York (USA): The Macmillan Company.

Sudono, Anggani. 2000. Sumber Belajar dan Alat Permainan (untuk Pendidikan Anak Usia Dini). J akarta: PT. Grasindo.

Sujiono, Yuliani Nurani, dkk. 2006. Metode Pengembangan Kognitif. Jakarta: Penerbit Universitas Terbuka.

Suparno, Paul. 2004. Teori Inteligensi Ganda dan Aplikasinya di Sekolah (Cara Menerapkan Teori
Multiple Intelligences Howard Gardner). Yogyakarta: Kanisius.

Tim artikata.com. 2012. Definisi Indigenous. www.artikata.com. 
J urnal Pendidikan Anak, Volume 1, Edisi 1, J uni 2012 